\title{
Effect Azola (Azola pinnata) Feeding on Growth Performance and Carcass Traits of Crossbred Pigs
}

\author{
Kiranpal Singh Saini", Biswajit Roy, G. P. Lakhani, A. K. Jain and Sudipta Ghosh \\ Department of Livestock Production and Management, College of Veterinary Science and \\ Animal Husbandry, NDVSU, Jabalpur, M.P., India \\ *Corresponding author
}

\section{A B S T R A C T}

\begin{tabular}{|l|}
\hline Ke y w or d s \\
Crossbred pigs, \\
azolla, average \\
daily gain, carcass \\
traits
\end{tabular}

\section{Introduction}

The pig rearing constitutes the livelihood of rural poor belonging to the lowest socioeconomic strata. The total pig population in India was 10.29 millions and contributes around $2.01 \%$ of total livestock population (Livestock census, 2012). Pigs are the most prolific among the domestic animals. Their growth rate is fast and they use cereal byproducts efficiently and give higher dressing percentage at younger ages. There is considerable scope for pig farming as a profitable enterprise in rural areas (Tudu et al.,
The study was conducted at Livestock farm, Adhartal, College of Veterinary Science \& Animal Husbandry, N.D.V.S.U., Jabalpur (M.P.) for five months. A total of 21 crossbred pigs (about 4 months of age) were selected and randomly distributed in three different groups (G1, G2 and G3) each group containing seven animals. Diets were formulated as (CAR (2013) standard. Composition of the diets (Table-1) are as follows; GG-3; concentrate mixture-3 $(70 \%)+$ dried azolla $(30 \%)$. At the end of the experiment, the two animals from each group were slaughtered for carcass evaluation. Daily feed intake was significantly $(\mathrm{P}<0.05)$ varied among the groups. Highest daily feed intake $(\mathrm{kg} / \mathrm{pig} / \mathrm{day})$ was observed in G3 group (1.99) and lowest value observed in G1 group (1.90). Average daily gain $(\mathrm{ADG})$ were significantly $(\mathrm{P}<0.01)$ different and highest $\mathrm{ADG}(\mathrm{g} / \mathrm{pig})$ was observed in group G2 (385.64) and lowest ADG (g/pig) observed in G1 group (359.01). Carcass characteristics were not significantly varied among the experimental groups. Finally, the study concluded that azolla could be fed to the growing crossbred pigs

2015). They consume wide variety of feedstuffs including industrial waste, kitchen waste, plant materials, etc. Among the various alternate feed resources, a wonderful plant called Azolla can be used as livestock feed. Azolla has long been used as green manure. It is very rich in proteins, essential amino acids, vitamins ( $\mathrm{A}, \mathrm{B}_{12}$ and $\beta$ carotene) and growth promoter intermediaries and minerals viz., calcium, phosphorus, potassium, iron, copper, magnesium, etc. (Letermea et al., 2010). Azolla can be economically fed to sheep, goat, pig and rabbits as feed substitute (Pillai et al., 2002). In India, azolla is found floating on the 
water in the shallow ditches and in channels. Azolla can fix atmospheric nitrogen with help of blue green algae, Anabaena azollae, found in cavities of dorsal part of leaves. This fact makes the azolla tend to contain relatively high levels of nitrogen and can be a protein source for animal feeding. There is paucity of information regarding use of azolla in the diet of crossbred pigs. Hence, the present study was designed to evaluate the effect of azolla feeding on growth performance and carcass traits of crossbred pigs.

\section{Materials and Methods}

The study was conducted at pig unit of Livestock farm, Adhartal, College of Veterinary Science \& A.H., Nanaji Deshmukh Veterinary Science University, Jabalpur (M.P.). The study was conducted for a period of nine months (July, 2016 to March, 2017) at Livestock farm, Adhartal, Jabalpur. A total of 21 growing crossbred pigs were randomly assigned into three different groups, with seven animals in each group. The preexperimental period of 15 days was allowed to get the experimental animals adjusted before actual start of actual experiment. Diets were formulated as per ICAR (2013) standard. Animals of the group- 1 was receiving only basal diet, whereas diet of the group-2 and group-3 were $15 \%$ dried azola $+85 \%$ basal diet and $30 \%$ dried azolla $+70 \%$ basal diet, respectively. Other than feed, all the pigs were maintained under same managemental conditions. Body weight of all animals was recorded fortnightly basis in the morning before feeding with use of platform type electronic weighing balance. At the end of the experiment, the two animals from each group were slaughtered for carcass evaluation. Proper fasting one day prior to slaughter was done. The weight before slaughter and antemortem examinations was carried out. The fallowing measurements were taken after slaughter of the animals. Carcass traits like dressing percentage, carcass length, backfat thickness were measured. Data were analysed, using ANOVA described by Snedcor and Cochran (1994). Means showing significant differences in the ANOVA table were compared using the Duncan Multiple Range Test (Steel and Torrie, 1980).

\section{Results and Discussion}

Daily feed intake was evaluated at fortnight interval and indicated in table 2. Overall daily feed intake was not significantly varied among the groups. Highest daily feed intake (kg/pig) was observed in G3 group $(1.99 \pm 0.01)$ and lowest value observed in G1 group $(1.90 \pm 0.01)$. It was also observed in the present study that as the inclusion of azolla in the diet increases above 50 percent level, the feed intake starts declining. In G3 group, 30\% azolla was included in the diet and significantly $(\mathrm{P}<0.05)$ lower feed intake was observed inG1 group in comparison to the G2, and G3 groups. Higher feed intake was observed in G3 group (1.99) in comparison to the G2 group (1.92), however difference was non-significant. In the present study, overall daily feed intake was not significantly varied among the groups. Overall average feed intake in terms of per cent body of crossbred growing pigs were $3.39 \pm 0.12, \quad 3.37 \pm 0.16$, and $3.46 \pm 0.19$ per cent, respectively for the G1, $\mathrm{G} 2$, and G3 groups and no significant difference were observed among the experimental groups. The result obtained in the present study is in accordance with the reports of Cherryl et al., (2013). It is supported by the findings of Shamna et al., (2013), who have reported that growth and feed conversion efficiency in quails on Azolla pinnata at 5\% displacement level of the basal ration was as good as the basal diet, besides it was more economical due to less expenditure on feed. In the present study, $15 \%$ and $30 \%$ azolla was added to the diet of group 2 and group 3 , respectively. 
Table.1 Gross composition (\%) of concentrate mixture/diet used in the experiment

\begin{tabular}{|l|c|}
\hline Ingredients & Proportion $(\mathbf{K g})$ \\
\hline Yellow maize & 37 \\
\hline Rice polish & 16.5 \\
\hline Wheat bran & 14 \\
\hline Undecorticated ground nut cake & 14 \\
\hline De-oiled rice polish & 10 \\
\hline Jawala fish(60\%Protein) & 6 \\
\hline Mineral mixture & 2 \\
\hline Common salt & 0.5 \\
\hline Total & $\mathbf{1 0 0}$ \\
\hline
\end{tabular}

Table.2 Effect of azolla feeding on growth performance and carcass traits of crossbred pigs

\begin{tabular}{|c|c|c|c|}
\hline Groups & G1 & G2 & G3 \\
\hline \multicolumn{4}{|c|}{ Feed intake and growth performance } \\
\hline $\begin{array}{l}\text { Average daily feed intake } \\
\text { (kg/pig/day) }\end{array}$ & $1.90 \pm 0.01$ & $1.92 \pm 0.0 .01$ & $1.99 \pm 0.0 .01$ \\
\hline $\begin{array}{l}\text { Average daily gain } \\
\text { (kg/pig/day) }\end{array}$ & $0.359 \pm 12.50$ & $0.385 \pm 13.20$ & $0.382 \pm 12.96$ \\
\hline Feed conversion ratio (FCR) & $5.46 \pm 0.20$ & $5.24 \pm 0.17$ & $5.50 \pm 0.18$ \\
\hline \multicolumn{4}{|c|}{ Carcass traits } \\
\hline Fasting weight (kg) & $91.15 \pm 4.96$ & $87.90 \pm 3.53$ & $93.35 \pm 5.26$ \\
\hline Hot carcass weight $(\mathrm{kg})$ & $59.30 \pm 2.96$ & $63.70 \pm 3.21$ & $61.70 \pm 3.92$ \\
\hline Dressing percent & $67.47 \pm 1.93$ & $68.27 \pm 2.96$ & $67.71 \pm 2.91$ \\
\hline Carcass length $(\mathrm{cm})$ & $84.77 \pm 5.27$ & $86.12 \pm 4.92$ & $85.37 \pm 4.39$ \\
\hline \multicolumn{4}{|l|}{ Back fat thickness (mm) } \\
\hline At first ribs & $35.71 \pm 1.29$ & $35.21 \pm 1.71$ & $36.21 \pm 1.92$ \\
\hline At last ribs & $16.37 \pm 1.02$ & $16.22 \pm 1.22$ & $16.96 \pm 0.97$ \\
\hline At rump & $17.12 \pm 0.91$ & $14.92 \pm 0.79$ & $15.96 \pm 0.71$ \\
\hline
\end{tabular}

Average daily gain (ADG) of crossbred growing pigs was presented in Table 2. Statistical analysis of the parameter revealed that they were significantly $\quad(\mathrm{P}<0.01)$ different.

Highest ADG (kg/pig/day) was observed in group G2 (0.385) and lowest ADG (kg/pig/day) observed in G1 group (0.359). Initial average body weights $(\mathrm{kg} / \mathrm{pig})$ of the experimental groups were almost similar and ranges from 32.43 to 32.72 . At the end of the experiment lowest average body weights (kg/pig) was found in the G1 group (87.72) and highest in the G3 group (91.42).

Efficiency of utilisation of feed was measured through feed conversion ratio and protein conversion ratio. In the present study, overall FCR was significantly $(\mathrm{P}<0.01)$ varied among the experimental groups. Lowest FCR value was reported in G2 group (5.24) and highest in G3 group (5.50). FCR value indicated that how efficiently the feedstuffs are utilised for the production purpose. Parthasarthy et al., (2003) studies conducted with desi pigs fed 
with isonitrogenous concentrate mixtures containing sun-dried azolla revealed that azolla can be incorporated up to 30 per cent without any considerable adverse effect on growth.

Carcass characteristics were determined after slaughter of experimental pigs. Two animals from each group having higher body weight were slaughter after completion of experimental period. To evaluate the carcass characteristics, parameters like hot carcass weight, dressing per cent, carcass length and back fat thickness were observed. Back fat thickness was measured in three points namely; first ribs, last ribs and rump. Carcass characteristics are presented in table 2 . Dressing per cent were $67.47 \pm 1.93$, $68.27 \pm 2.97$ and $67.71 \pm 2.91$, respectively for the G1, G2, and G3, groups and the values were not significantly varied. Carcass length and back fat thickness was also not significantly varied among the groups. Similar findings were observed in other studies (Wadhwani et al., 2010., Tamang and Samanta, 1993), with the feeding of azolla.

Finally, the study concluded that azolla can replace $30 \%$ concentrate mixture without affecting body weight gain, feed intake and carcass traits.

\section{References}

Cherryl DM, Prasad RMV, Jagadeeswara RS, Jayalaxmi P and Eswar RB. 2013. Effect of inclusion of Azolla pinnata on the haematological and carcass characteristics of crossbred large white yorkshire pigs. Veterinary World, 7(2): 78-82.
ICAR 2013. Nutrient Requirements of Pig. Indian Council of Agriculture Research, New Delhi.

Letermea P, Angela M, Diana C and Buldgen A. 2010. Nutritional value and intake of aquatic ferns (Azolla filiculoides) in sows. Animal Feed Science and Technology, 155(1): 55-64.

Livestock census 2012. Department of Animal Husbandry and Dairying, Ministry of Agriculture, Government of India, New Delhi.

Parthasarthy R, Gowri AM, Gajendran K and Hariharan P. 2003. Azolla as feed source for desi pigs. Azolla in pigs: Cheiron, Farmers Training Centre, Tamilnadu Veterinary Animal Science University, Tiruvarur.

Pillai PK, Premalatha S and Rajamony S. 2002. Azolla-a sustainable feed substitute for livestock, leisa India, 4: 15-17.

Snedecor GW and Cochran WG. 1994. Statistical Methods, Affiliated East West Press, New Delhi, $142 \mathrm{p}$.

Steel RGD and Torrie JH. 1980. Principles and procedures of statistics. A biometrical approach. $2^{\text {nd }}$ Edn. Mc Graw Hill Book Co., New York, NY, USA.

Tamang Y and Samanta G. 1993. Feeding value of Azolla (Azolla pinnata) an aquatic fern in Black Bengal goats. Indian Journal of Animal Science, 63(2): 188-191.

Tudu NK, Pyne SK, Goswami KK, Ghoshand N and Roy DC. 2015. Socio-Economic profile and management practices of tribal pig farmers in West Bengal. Indian Journal of Research, 4: 1-4.

Wadhwani KN, Parnerkar S, Saiyed LH and Patel AM. 2010. Feedlot performance of weaner lambs on conventional and nonconventional total mixed ration. Indian Journal of Animal Research, 44(1): 16-21.

\section{How to cite this article:}

Kiranpal Singh Saini, Biswajit Roy, G. P. Lakhani, A. K. Jain and Sudipta Ghosh. 2018. Effect Azola (Azola pinnata) Feeding on Growth Performance and Carcass Traits of Crossbred Pigs. Int.J.Curr.Microbiol.App.Sci. 7(06): 3813-3816. doi: https://doi.org/10.20546/ijcmas.2018.706.448 